\title{
ANALISIS PENGARUH KONSUMSI RUMAH TANGGA, INVESTASI, DAN JUMLAH USAHA TERHADAP PERTUMBUHAN EKONOMI DI KOTA SURABAYA
}

\section{Ayu Putri Islamiah, Wiwin Priana, Muhammad Wahed}

Universitas Pembangunan Nasional (UPN) Veteran Jawa Timur, Indonesia

Email: putriayuislamiah@gmail.com,wiwinpriana10@gmail.com, muhammadwahed124@gmail.com

\begin{tabular}{ll}
\hline INFO ARTIKEL & ABSTRACT \\
\hline Diterima & The economy is again changing economic change. If the \\
1 Juni 2021 & actual total remuneration of the use of production factors \\
Direvisi & in the year is higher than the previous year, namely the \\
10 Juni 2021 & growing sub-district. In other words, if people's income \\
Disetujui & in the year is still large from people's income in the year, \\
15 Juni 2021 & then it can be said that the economy will be exposed. The \\
\hline Keywords: & purpose of this study is to analyze the influence of \\
economic & grousehold consumption on economic growth in \\
household & consumption,, \\
investment & Surabaya. Analyzing the influence of investment on \\
& economic growth in Surabaya. Analyzing the influence of \\
& business on the economy in Surabaya. The method in this \\
& study uses quantitative method, because this research \\
analyzes with numbers. Which data is the 20th data for \\
this study. Which data is the 20th data for this study. The \\
results of the analysis in which Household Consumption \\
ben positive and good to the Economic Economy of \\
Surabaya. This becomes, if Household Consumption is \\
injured, then the Economic Economy of Surabaya city \\
will also be in a good direction.
\end{tabular}

ABSTRAK

Pertumbuhan ekonomi adalah proses perubahan kondisi ekonomi. Jika total remunerasi aktual penggunaan faktorfaktor produksi pada tahun tertentu lebih tinggi dari tahun sebelumnya, dianggap perekonomian sedang tumbuh. Dengan kata lain, jika pendapatan aktual masyarakat pada tahun tertentu lebih besar dari pendapatan aktual masyarakat pada tahun sebelumnya, maka dapat dikatakan perekonomian akan mengalami pertumbuhan. Tujuan dari penelitian ini adalah untuk menganalisa pengaruh konsumsi rumah tangga terhadap pertumbuhan

$\begin{array}{ll}\text { How to cite: } & \text { Ilamiah Ayu Putri, dkk (2021). Analisis Pengaruh Konsumsi Rumah Tangga, Investasi, Dan Jumlah } \\ & \text { Usaha Terhadap Pertumbuhan Ekonomi Di Kota Surabaya. Jurnal Syntax Admiration 2(6). } \\ & \text { https://doi.org/10.46799/jsa.v2i6.241 } \\ \text { E-ISSN: } & \text { 2722-5356 } \\ \text { Published by: } & \text { Ridwan Institute }\end{array}$




\begin{tabular}{ll}
\hline & ekonomi di Kota Surabaya. Menganalisa pengaruh \\
& investasi terhadap pertumbuhan ekonomi di Kota \\
& Surabaya. Menganalisa pengaruh jumlah usaha terhadap \\
& pertumbuhan ekonomi di Kota Surabaya. Metode dalam \\
& penelitian ini menggunakan pendekatan kuantitatif, \\
& karena penelitian ini disajikan dengan angka-angka. Data \\
& yang digunakan untuk penelitian ini adalah data \\
& sekunder. Data yang digunakan untuk penelitian ini \\
& adalah data sekunder. Hasil analisis menunjukkan bahwa \\
& Konsumsi Rumah Tangga berpengaruh positif dan \\
& signifikan terhadap Pertumbuhan Ekonomi Kota \\
& Surabaya. Hal ini berarti, jika Konsumsi Rumah Tangga \\
Kata Kunci: & mengalami peningkatan, maka Pertumbuhan Ekonomi \\
pertumbuhan & Kota Surabaya juga akan mengalami peningkatan yang \\
konsumsi rumah tangga, & \\
investasi & signifikan.
\end{tabular}

\section{Pendahuluan}

Pertumbuhan ekonomi adalah proses perubahan kondisi ekonomi. Negara ini telah bergerak menuju keadaan yang lebih baik untuk jangka waktu tertentu. Jika tingkat kegiatan ekonomi lebih tinggi dari tingkat pada periode sebelumnya maka perkembangan perekonomian akan berubah (Gwijangge et al., 2018). Hal ini dikarenakan pertumbuhan ekonomi memungkinkan perkembangan ekonomi di banyak daerah. Menurut Kuznets, pertumbuhan ekonomi adalah peningkatan jangka panjang dalam kemampuan suatu negara untuk menyediakan berbagai barang ekonomi yang lebih luas kepada penduduknya. Kemampuan ini tumbuh dengan kemajuan teknologi dan diperlukan penyesuaian kelembagaan dan ideologis (Fau, 2018). Karena kegiatan ekonomi dasar adalah proses pemanfaatan faktor-faktor produksi untuk menghasilkan keluaran, maka proses ini pada gilirannya akan menimbulkan aliran remunerasi bagi faktor-faktor produksi yang dimiliki oleh masyarakat (Basri et al., 2010). Peningkatan faktor produksi pemilik juga akan meningkat (Lumintang, 2013) Jika total remunerasi aktual penggunaan faktor-faktor produksi pada tahun tertentu lebih tinggi dari tahun sebelumnya, dianggap perekonomian sedang tumbuh. Dengan kata lain, jika pendapatan aktual masyarakat pada tahun tertentu lebih besar dari pendapatan aktual masyarakat pada tahun sebelumnya, maka dapat dikatakan perekonomian akan mengalami pertumbuhan. Salah satu tolak ukur terpenting untuk mengukur tingkat pertumbuhan ekonomi suatu negara adalah dengan melihat produk domestik bruto (PDB).

PDB mencatat nilai pelindung barang dan jasa akhir yang diproduksi oleh suatu perekonomian di suatu negara dalam satu tahun (Yuniandra et al., 2007). Tiga metode yang dapat digunakan untuk menghitung PDB suatu negara, yaitu 1). metode pendapatan, 2) metode pengeluaran sebaiknya, 3) metode nilai tambah.

Salah satu tolak ukur terpenting untuk mengukur tingkat pertumbuhan ekonomi suatu negara adalah dengan melihat produk domestik bruto (PDB). Pentingnya 
penelitian ini dilakukan untuk mengetahui pengaruh antara konsumsi rumah tangga, investasi, dan jumlah usaha terhadap pertumbuhan ekonomi.

Surabaya merupakan ibu kota provinsi Jawa Timur, sekaligus menjadi pusat perekonomian di Jawa Timur. Dilihat dari PDRB Kota Surabaya yang setiap tahun mengalami peningkatan.

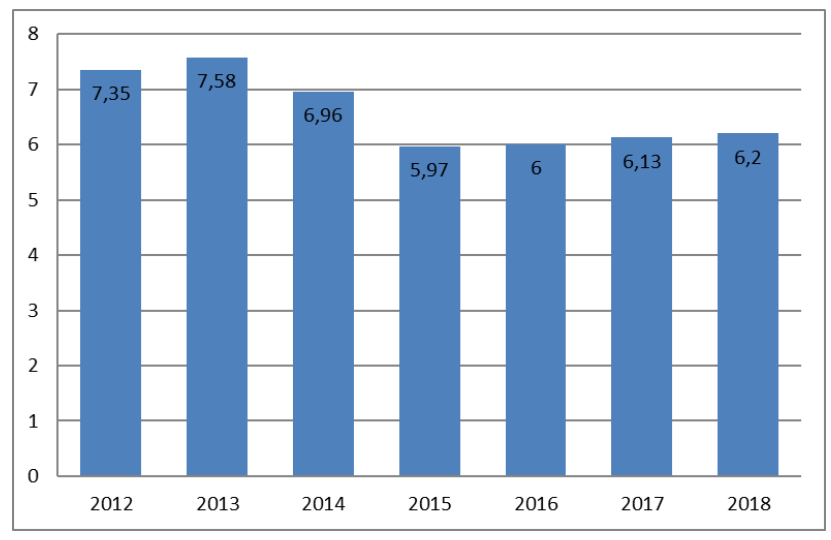

Gambar 1

Laju Pertumbuhan Ekonomi Kota Surabaya

Sumber: BPS Kota Surabaya, 2021

Pertumbuhan ekonomi Surabaya berfluktuasi setiap tahun. Pertumbuhan ekonomi disebabkan oleh faktor-faktor yang mempengaruhi pertumbuhan ekonomi, antara lain pertumbuhan konsumsi, investasi dan jumlah usaha. Tahun lalu, perekonomian Surabaya mampu tumbuh dengan stabil sekitar 7\% (7\%). Laju pertumbuhan ekonomi lebih tinggi dari Jawa Timur dan rata-rata nasional. Pertumbuhan ekonomi Surabaya mulai melambat pada tahun 2014 dan 2015 dengan tingkat pertumbuhan sebesar 6\%. Penyebab perlambatan pertumbuhan ekonomi adalah ketidakstabilan ekonomi global. Tren penurunan ini juga terjadi di Jawa Timur dan seluruh nusantara.

Dibandingkan dengan tahun sebelumnya, perekonomian Surabaya tumbuh sebesar $6,20 \%$ pada tahun 2018. Dilihat dari cara produksi, wilayah usaha pelayanan kesehatan dan kegiatan kemasyarakatan mencapai pertumbuhan tertinggi yaitu mencapai 7,81\%. Diikuti oleh industri akomodasi dan katering sebesar 7,80\%, transportasi dan industri penyimpanan sebesar 7,56\%. Berdasarkan metode pengeluaran, segmen ekspor mengalami pertumbuhan tertinggi yaitu segmen ekspor sebesar 10,50\%, diikuti segmen impor sebesar 9,45\%, dan segmen pembentukan modal tetap sebesar 6,36\% (Anggoro, 2015).

Pada tahun 2018, tiga bidang usaha utama PDRB di Surabaya adalah: perdagangan grosir dan eceran, industri bengkel mobil dan sepeda motor meningkat $27,94 \%$, industri pengolahan meningkat $18,58 \%$, akomodasi dan penyediaan makanan dan minuman meningkat $15,95 \%$. Sedangkan dari sisi pengeluaran, komponen pengeluaran konsumsi rumah tangga (PKRT) memberi kontribusi terbesar yaitu 
sebesar 58,69 persen, menyusul komponen ekspor barang dan jasa sebesar 38,39 persen dan impor barang dan jasa sebesar 32,45 persen.

Secara nominal, PDRB Kota Surabaya tahun 2018 atas dasar harga berlaku mencapai Rp. 554,59 triliun dan PDRB atas dasar harga konstan 2010 mencapai Rp. 387,33 triliun. Sektor yang sangat berperan dan dominan penyumbang PAD (Pendapatan Asli Daerah) terbesar di kota Surabaya yaitu perdagangan, hotel dan restoran, dan angkutan atau transportasi. Menurut Pakar ekonomi Universitas Airlangga Surabaya (UNAIR) Rudi Purwono kota Surabaya termasuk kota yang menjanjikan untuk berinvestasi. Beliau mengatakan bahwa pertumbuhan dan sarana infrastruktur turut menopang kota Surabaya sebagai kota jasa dan perdagangan.

Beberapa para ahli telah mengemukakan faktor-faktor yang menyebabkan meningkatnya pertumbuhan ekonomi salah satunya Keynes. Berdasarkan pendekatan Keynes, pertumbuhan ekonomi ditentukan oleh peningkatan pengeluaran (Mankiw, 2006). Salah satu faktor yang menyebabkan pertumbuhan ekonomi menurut pendekatan Keynes yaitu pengeluaran konsumsi rumah tangga. Konsumsi sebagai indikator kesejahteraan di beberapa wilayah. Di kebanyakan wilayah konsumsi rumah tangga memberikan dampak kepada pendapatan. Di kebanyakan wilayah pengeluaran konsumsi rumah tangga sekitar $60-75 \%$ dari pendapatan. Konsumsi rumah tangga juga berdampak dalam menentukan fluktuasi kegiatan dari satu periode ke periode lainnya. Dalam jangka panjang pengaruh konsumsi rumah tangga dan tabungan masyarakat sangat besar terhadap pertumbuhan ekonomi (Gadeng, 2011). Semakin tinggi tingkat pengeluaran konsumsi rumah tangga, semakin rendah penghasilan rumah tangga.

Investasi merupakan suatu pembelian barang-barang modal dan peralatan produksi untuk meningkatkan suatu perekonomian di masa depan (Gadeng, 2011). Investasi juga merupakan salah satu indikator pertumbuhan ekonomi suatu wilayah. Dengan adanya investasi yang bertujuan untuk pembelian barang-barang dan jasa akan dapat meningkatkan PDRB riil dan akan berpengaruh positif terhadap pertumbuhan ekonomi.

Kota surabaya sebagai pusat perekonomian di Jawa Timur, dimana banyak perusahaan baik skala global maupun nasional yang beroperasi di Surabaya. Maka dari itu dengan banyaknya sejumlah unit usaha yang berkembang dari tahun ke tahun di Surabaya juga dapat mempengaruhi pertumbuhan PDRB. Menurut teori Schumpeter, kemajuan perekonomian sangat ditentukan oleh adanya pengusaha. Pengusaha yang unggul akan menciptakan suatu produksi yang unggul juga. Semakin bertambahnya jumlah produksi akan mempengaruhi pertumbuhan perekonomian di suatu wilayah. Hal ini dibuktikan adanya penelitian dari (Robiani, 2005) bahwa nilai tambah sektor industri berpengaruh signifikan terhadap pertumbuhan ekonomi di Sumatera Selatan. Berikut Grafik Pertumbuhan Ekonomi, Konsumsi Rumah Tangga, Investasi, dan Jumlah Usaha di Kota Surabaya periode 2014-2018. 


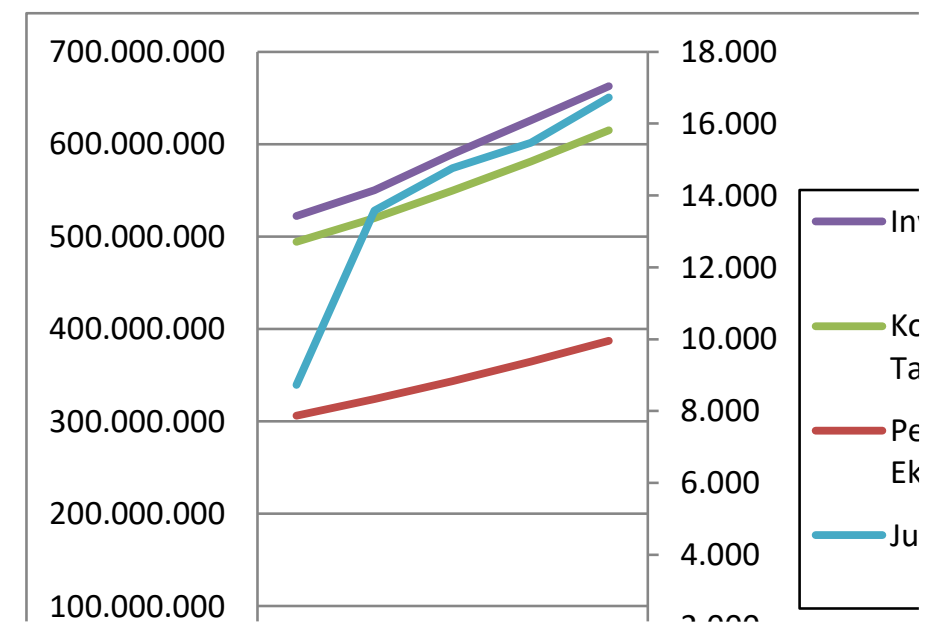

Berdasarkan rumusan masalah yang diuraikan sebelumnya, maka yang menjadi tujuan umum penelitian adalah untuk menganalisa pengaruh konsumsi rumah tangga terhadap pertumbuhan ekonomi di Kota Surabaya. Menganalisa pengaruh investasi terhadap pertumbuhan ekonomi di Kota Surabaya. Menganalisa pengaruh jumlah usaha terhadap pertumbuhan ekonomi di Kota Surabaya.

\section{Metode Penelitian}

Penelitian ini dilakukan oleh penulis di Kota Surabaya. Pemilihan Kota Surabaya ini didasarkan pertimbangan bahwa Kota Surabaya merupakan ibu kota Provinsi Jawa Timur. Selain itu Surabaya juga menjadi pusat perekonomian di Jawa Timur. Dengan pertimbangan tersebut maka penulis tertarik meneliti mengenai pertumbuhan ekonomi di Kota Surabaya dengan variabel pendukung yaitu konsumsi rumah tangga, investasi, dan jumlah usaha.

Pendekatan dalam penelitian ini adalah pendekatan kuantitatif, karena penelitian ini disajikan dengan angka-angka. Hal ini sesuai dengan pendapat (Utama, 2013) yang mengemukakan penelitian kuantitatif adalah pendekatan penelitian yang banyak dituntut menggunakan angka, mulai dari pengumpulan data, penafsiran terhadap data tersebut, serta penampilan hasilnya.

Jenis data yang digunakan adalah data kuantitatif, yaitu data yang diukur dalam suatu skala numerik (angka), dan biasanya menggunakan sampel yang lebih banyak, serta menggunakan pertanyaan atau observasi terstruktur (Kuncoro, 2003).

Data yang digunakan untuk penelitian ini adalah data sekunder. Data sekunder adalah data yang diperoleh lewat pihak lain, tidak langsung diperoleh dari peneliti dari subjek penelitiannya. Data sekunder biasanya berwujud dokumentasi atau data laporan yang telah tersedia (Azwar, 2000). Penggunaan data pada penelitian ini meliputi variabel terikat yaitu pertumbuhan ekonomi dan variabel bebas yaitu konsumsi rumah tangga, investasi (PMDN dan PMA) dan unit usaha. Dalam penelitian ini data yang digunakan meliputi data, yakni: 1) pertumbuhan PDRB di kota Surabaya (20010-2019), 2) konsumsi Rumah Tangga di kota Surabaya (2010-2019), 3) total Investasi di Kota Surabaya (2010-2019). 4). Jumlah Unit Usaha di kota Surabaya (2010-2019). 
Teknik pengumpulan data yang digunakan dalam penelitian adalah dengan menggunakan metode studi pustaka, yaitu metode mempelajari dan menganalisis buku-buku jurnal dan data-data olahan. Pengumpulan dengan metode seperti ini bertujuan untuk mendapatkan data yang akurat dan relevan. Data yang digunakan berasal dari data sekunder Disperindag Kota Surabaya, Badan Pusat Statistik (BPS) Kota Surabaya, Dinas Penanaman Modal (DPM) Kota Surabaya, dan sumber-sumber kepustakaan lain yang terkait dengan penelitian ini.

\section{Hasil dan Pembahasan}

\section{A. Hasil Penelitian}

1. Analisis Data

a. Analisis Deskriptif

\section{Tabel 1}

Statistik Deskriptif Variabel Penelitian

\begin{tabular}{ccccc}
\hline Variabel & Minimum & Maximum & Mean & SD \\
\hline $\begin{array}{c}\text { Pertumbuhan } \\
\text { Ekonomi (Y) }\end{array}$ & 5,79 & 7,58 & 6,5210 & 0,65954 \\
\hline $\begin{array}{c}\text { Konsumsi Rumah } \\
\text { Tangga (X1) }\end{array}$ & 18,78 & 19,29 & 19,0500 & 0,17237 \\
\hline Investasi (X2) & 18,02 & 18,54 & 18,2900 & 0,17327 \\
\hline Jumlah Usaha (X3) & 4,98 & 5,76 & 5,3350 & 0,19449 \\
\hline
\end{tabular}

Sumber: Hasil Olah Data Statistik Deskriptif, 2021

Berdasarkan Tabel 1 dapat dijelaskan oleh yang berikut:

1) Pertumbuhan ekonomi rata-rata $(Y)$ dari 6.5210 , nilai minimum 5,79 , nilai maksimum 7,58, dan standar deviasi 0,65954 dengan jumlah pengamatan (n) dari 10. Nilai rata-rata pertumbuhan ekonomi (Y) mendekati Nilai deviasi standar 0,65954, sehingga ketidakteraturan data pertumbuhan ekonomi rendah (Y).

2) Konsumsi rumah tangga rata-rata (X1) adalah 19.0500 , nilai minimum 18,78, nilai maksimum 19.29, dan standar deviasi 0,17237 dengan jumlah pengamatan (n) dari 10. Nilai konsumsi rata-rata rumah tangga (X1) cukup Dekat dengan nilai deviasi standar 0,480, dengan demikian penyimpangan dalam data konsumsi rumah tangga (X1) cukup rendah.

3) Rata-rata investasi (X2) sebesar 18.2900 , nilai minimum 18.02 , nilai maksimum 18,54, dan standar deviasi 0,221278 dengan jumlah pengamatan (n) dari 10. Nilai investasi rata-rata (X2) hanya mendekati standar Nilai deviasi 0,17327 , sehingga deviasi data investasi (X2) cukup rendah.

4) Jumlah rata-rata bisnis (x3) adalah 5.3350, nilai minimum 4,98, nilai maksimum 5,76, dan standar deviasi 0,19449 dengan sejumlah pengamatan (n) dari 10. Nilai rata-rata jumlah bisnis ( X3) Mendekati 
nilai deviasi standar 0,19449 sehingga deviasi data dalam bisnis rendah (X3).

b. Pengujian Asumsi Klasik

1) Uji Normalitas

Uji normalitas bertujuan untuk menguji apakah dalam model regresi variabel dependen dan variabel independen memiliki distribusi normal atau tidak. Model regresi yang baik adalah memiliki distribusi data normal atau dekat dengan normal (Ghozali et al., 2016). Untuk menguji normalitas, dapat menganalisis nilai tes Smirnov Kolmogorov. Dasar pengambilan keputusan adalah, jika nilai probabilitas $>0,05$, model regresi memenuhi asumsi normalitas, model regresi memenuhi asumsi normalitas dan sebaliknya. Hasil uji normalitas dengan Kolmogorov Smirnov Test sebagai berikut:

\section{Tabel 2}

Hasil Uji Normalitas dengan Kolmogorov Smirnov Test

\begin{tabular}{cccc}
\hline Variabel & Sig. & Nilai Kritis & Keterangan \\
\hline Residual & 0,834 & 0,05 & Normalitas \\
\hline
\end{tabular}

Sumber: Lampiran Hasil Uji Asumsi Klasik, 2021

Berdasarkan hasil uji normalitas dengan Kolmogorov Smirnov Test di atas terlihat bahwa nilai probabilitas $=0,834>0,05$, maka model regresi memenuhi asumsi normalitas.

2) Uji Multikolinearitas

Tes multicollinearity adalah situasi di mana satu atau lebih variabel independen dapat dinyatakan sebagai kombinasi linear dari variabel independen lainnya. Salah satu asumsi regresi linier klasik adalah tidak adanya multikolinieritas sempurna (tidak ada multikolinieritas yang sempurna). Model regresi dikatakan terpapar multicollinearity jika hubungan linear sempurna atau tepat di antara beberapa atau semua variabel independen. Akibatnya, akan sulit untuk melihat pengaruh individu pada variabel gratis ke non-bebas (Ghozali et al., 2016). Deteksi multikolinearitas dalam penelitian ini dilakukan dengan metode VIF.

Kriteria Tes:

Jika VIF $\geq 10$, maka Ho ditolak

Jika vif $<10$, maka Ho diterima

Hasil uji multikolinearitas dengan metode VIF adalah sebagai berikut: 
Tabel 3

Hasil Uji Multikolinearitas dengan Metode VIF

\begin{tabular}{cccc}
\hline Persamaan & VIF & Nilai Kritis & Keterangan \\
\hline $\mathrm{X} 1$ & 1,671 & 10 & $\begin{array}{c}\text { Tidak terkena } \\
\text { multikolinearitas }\end{array}$ \\
\hline $\mathrm{X} 2$ & 1,868 & 10 & $\begin{array}{c}\text { Tidak terkena } \\
\text { multikolinearitas }\end{array}$ \\
\hline $\mathrm{X} 3$ & 4,641 & 10 & $\begin{array}{c}\text { Tidak terkena } \\
\text { multikolinearitas }\end{array}$ \\
\hline
\end{tabular}

Sumber: Lampiran Hasil Olah Data Regresi Linier Berganda, 2021.

Berdasarkan hasil uji multikolinearitas dengan metode VIF, nilai VIF < 10, artinya bahwa semua variabel bebas tidak terjadi multikolinearitas, sehingga tidak membiaskan interpretasi hasil analisis regresi.

3) Uji Autokorelasi

Autokorelasi adalah situasi di mana faktor yang mengganggu (istilah kesalahan) pada periode tertentu berkorelasi dengan faktor-faktor yang mengganggu dalam periode lain. Faktor-faktor yang tidak dijalankan tidak acak (tidak dirandom). Autokorelasi disebabkan oleh faktor ketimpangan (inersia), manipulasi data, kesalahan dalam menentukan model (spesifikasi bias), fenomena sarang laba-laba, dan penggunaan lag dalam model. Deteksi asumsi autokorelasi dalam penelitian ini dilakukan oleh uji Durbin-Watson.

Jika d-hitung < dL atau d-hitung > (4-dL), Ho ditolak, berarti ada autokorelasi

Jika dL $<$ d-hitung $<(4-\mathrm{dL})$, Ho diterima, berarti tidak terjadi autokorelasi

Jika dL $<$ d-hitung $<$ dU atau (4-dU) $<$ d-hitung < (4-dL), maka tidak dapat disimpulkan ada tidaknya autokorelasi.

Dari hasil regresi diperoleh nilai D-W statistik sebesar 2,854. Dengan $\mathrm{n}=10, \mathrm{k}=3$, dan taraf nyata $(\alpha) 5 \%$, maka nilai $\mathrm{dL}=0,525, \mathrm{dU}=$ 2,016, sehingga $(4-d U)=4-2,016=1,984$ dan $(4-d L)=4-0,525=3,475$.

\section{Tabel 4}

Hasil Uji Autokorelasi

\begin{tabular}{cc}
\hline Tingkat Autokorelasi (DW) & Jenis Autokorelasi \\
\hline$(4-\mathrm{DW} . \mathrm{L})<\mathrm{DW}<4$ & Ada Autokorelasi negatif \\
$(4-\mathrm{DW} . \mathrm{U})<\mathrm{DW}<(4-\mathrm{DW} . \mathrm{L})$ & Tanpa kesimpulan \\
$0,525<2,854<(3,475)$ & Tidak Ada Autokorelasi \\
DW.L $<$ DW $<$ DW.U & Tanpa Kesimpulan \\
$0<$ DW $<$ DW. L & Ada Autokorelasi positif \\
\hline Sumber: Lampiran Hasil Olah Data Regresi Linier Berganda, 2021.
\end{tabular}


Ternyata nilai D-W statistik sebesar 2,854 berada di daerah penerimaan Ho. Hal ini berarti model yang diestimasi tidak terjadi autokorelasi.

4) Uji Heteroskedastisitas

Homoskedasitas adalah situasi dimana varian $(\sigma 2)$ dari faktor gangguan atau istilah gangguan adalah sama untuk semua pengamatan $\mathrm{X}$. Penyimpangan pada asumsi ini disebut heteroscedasticity, yaitu jika varian $(\sigma 2)$ variabel tidak gratis (Yi) meningkat sebagai hasil dari meningkatnya variabel variabel independen (XI), varian Yi tidak sama (Ghozali et al., 2016). Deteksi heteroskedastisitas dalam penelitian ini dilakukan dengan metode Glejser. Caranya adalah dengan melihat nilai probabilitas> 0,05, sehingga tidak terpapar heteroskedastisitas (Ghozali et al., 2016). Hasil uji heteroskedastisitas dengan Glejser sebagai berikut:

\section{Tabel 5}

Hasil Uji Heteroskedastisitas dengan Glejser

\begin{tabular}{cccc}
\hline Variabel & Sig. & Nilai Kritis & Keterangan \\
\hline X1 & 0,723 & 0,05 & Homoskedastisitas \\
\hline X2 & 0,942 & 0,05 & Homoskedastisitas \\
\hline X3 & 0,438 & 0,05 & Homoskedastisitas \\
\hline
\end{tabular}

Sumber: Lampiran Hasil Olah Data Uji Asumsi Klasik, 2021.

Berdasarkan hasil uji heteroskedastisitas dengan menggunakan Glejser terlihat bahwa nilai probabilitas $>0,05$. Hal ini berarti model yang diestimasi bebas dari heteroskedastisitas.

\section{c. Analisis Regresi Linier Berganda}

Analisis dalam penelitian ini adalah Analisis Regresi Linier Berganda. Analisis ini digunakan untuk mengetahui pengaruh dari variabel Konsumsi Rumah Tangga (X1), Investasi (X2), dan Jumlah Usaha (X3) terhadap Pertumbuhan Ekonomi (Y). Berdasarkan hasil perhitungan dengan menggunakan program statistik komputer SPSS for Windows diperoleh hasil sebagai berikut:

Tabel 6

Hasil Regresi Linier Berganda

\begin{tabular}{ccccc}
\hline Variabel & $\begin{array}{c}\text { Koefisien } \\
\text { Regresi }\end{array}$ & $\begin{array}{c}\text { Standart } \\
\text { Error }\end{array}$ & $\begin{array}{c}\text { t- } \\
\text { statistik }\end{array}$ & Sig. \\
\hline Konstanta & 84,821 & 7,022 & 12,079 & 0,000 \\
\hline $\mathrm{X} 1$ & 11,145 & 2,427 & 4,593 & 0,004 \\
\hline $\mathrm{X} 2$ & 7,275 & 2,572 & 2,828 & 0,030 \\
\hline $\mathrm{X} 3$ & 0,178 & 0,453 & 0,394 & 0,707 \\
\hline $\mathrm{R}^{2}$ & $: 0,977$ & & & \\
\hline Adj. $\mathrm{R}^{2}$ & $: 0,965$ & & \\
\hline $\mathrm{F}$-statistik & $: 84,755$, Sig $=0,000$. & & \\
\hline $\mathrm{DW}$-statistik & $: 2,854$ & & \\
\hline $\mathrm{N}$ & $: 246$ & &
\end{tabular}


Sumber: Hasil Olah Data Regresi Linier Berganda, 2021.

Secara matematis hasil dari analisis regresi linier berganda tersebut dapat ditulis sebagai berikut:

$\mathrm{Y}=84,821+11,145 \operatorname{LnX} 1+7,275 \operatorname{LnX} 2+0,178 \operatorname{LnX} 3$

Pada persamaan di atas ditunjukkan pengaruh independen (X) terhadap dependen $(\mathrm{Y})$. Adapun arti dari koefisien regresi tersebut adalah:

1) $\mathrm{b} 0=84,821$

Artinya, apabila Konsumsi Rumah Tangga (X1), Investasi (X2), dan Jumlah Usaha (X3) sama dengan nol, maka Pertumbuhan Ekonomi (Y) sebesar 84,821 persen.

2) $\mathrm{b} 1=11,145$

Artinya apabila kenaikan Konsumsi Rumah Tangga (X1) sebesar 1 persen, maka Pertumbuhan Ekonomi (Y) naik sebesar 11,145 persen dengan asumsi variabel lain adalah konstan (ceteris paribus).

3) $\mathrm{b} 2=7,275$

Artinya apabila kenaikan Investasi (X2) sebesar 1 persen, maka Pertumbuhan Ekonomi (Y) naik sebesar 7,275 persen dengan asumsi variabel lain adalah konstan (ceteris paribus).

4) $\mathrm{b} 3=0,178$

Artinya apabila kenaikan Jumlah Usaha (X3) sebesar 1 persen, maka Pertumbuhan Ekonomi (Y) naik sebesar 0,178 persen dengan asumsi variabel lain adalah konstan (ceteris paribus).

d. Pengujian Statistik

1) Pengujian Hipotesis (Uji F)

Uji $F$ adalah uji simultan yang digunakan untuk mengetahui pengaruh variabel independen secara simultan terhadap variabel dependen. Diperoleh nilai Sig.F $=0,000<0,05$, maka Ho ditolak atau Ha diterima, artinya ada pengaruh secara simultan antara Konsumsi Rumah Tangga (X1), Investasi (X2), dan Jumlah Usaha (X3) terhadap Pertumbuhan Ekonomi (Y).

2) Pengujian Hipotesis (Uji t)

Uji t digunakan untuk membuktikan pengaruh Konsumsi Rumah Tangga (X1), Investasi (X2), dan Jumlah Usaha (X3) terhadap Pertumbuhan Ekonomi (Y) secara individual (uji t) dengan asumsi bahwa variabel yang lain tetap atau konstan. Berdasarkan hasil perhitungan dengan menggunakan program statistik komputer SPSS for Windows diperoleh hasil sebagai berikut: 


\section{Tabel 7}

Hasil Uji t

\begin{tabular}{ccc}
\hline Variabel & t-statistik & Sig.t \\
\hline X1 & 4,593 & 0,004 \\
\hline X2 & 2,828 & 0,030 \\
\hline X3 & 0,394 & 0,707 \\
\hline
\end{tabular}

Sumber: Hasil Olah Data Regresi Linier Berganda, 2021.

a) Pengujian Pengaruh Konsumsi Rumah Tangga (X1) terhadap Pertumbuhan Ekonomi (Y)

Berdasarkan hasil olah data diperoleh nilai Sig.t $=0,004<$ Level of Significant $=0,05$, maka Ho ditolak atau $\mathrm{Ha}$ diterima, artinya disimpulkan bahwa ada pengaruh positif dan signifikan Konsumsi Rumah Tangga (X1) terhadap Pertumbuhan Ekonomi (Y).

b) Pengujian Pengaruh Investasi (X2) terhadap Pertumbuhan Ekonomi (Y)

Berdasarkan hasil olah data diperoleh nilai Sig.t $=0,030<$ Level of Significant $=0,05$, maka Ho ditolak atau Ha diterima, artinya bahwa ada pengaruh positif dan signifikan Investasi (X2) terhadap Pertumbuhan Ekonomi (Y).

c) Pengujian Pengaruh Jumlah Usaha (X3) terhadap Pertumbuhan Ekonomi (Y)

Berdasarkan hasil olah data diperoleh nilai Sig.t $=0,707>$ Level of Significant $=0,05$, maka Ho ditolak atau Ha diterima, artinya disimpulkan bahwa ada pengaruh positif, tetapi tidak signifikan Jumlah Usaha (X3) terhadap Pertumbuhan Ekonomi (Y).

3) Pengujian Goodness of Fit

Hasil dari regresi dengan metode OLS (Ordinary Least Square) diperoleh R2 (Koefisien Determinasi) sebesar 0,965, artinya variabel dependen (Y) dalam model yaitu Pertumbuhan Ekonomi (Y) dijelaskan oleh variabel independen yaitu Konsumsi Rumah Tangga (X1), Investasi (X2), dan Jumlah Usaha (X3) sebesar 96,5\%, sedangkan sisanya sebesar $3,5 \%$ dijelaskan oleh faktor lain di luar model.

\section{B. Pembahasan}

\section{Pengaruh Konsumsi Rumah Tangga (X1) terhadap Pertumbuhan Ekonomi} (Y)

Hasil analisis regresi linier berganda menunjukkan bahwa konsumsi rumah tangga (X1) memiliki pengaruh positif dan signifikan terhadap pertumbuhan ekonomi (Y). Ini berarti, jika konsumsi rumah tangga (X1) meningkat, pertumbuhan ekonomi (Y) juga akan mengalami peningkatan yang signifikan. Hasil penelitian ini sesuai dengan hasil penelitian (Rafiq, 2016), (Tapparan, 2020) yang menyatakan konsumsi rumah tangga memiliki pengaruh positif atau signifikan terhadap pertumbuhan ekonomi. Menurut teori konsumsi Keynes, 
pihaknya berpendapat bahwa semakin tinggi pendapatan, tingkat pengeluaran konsumsi rumah tangga juga akan meningkat. Pengeluaran konsumsi rumah tangga adalah nilai belanja yang dilakukan oleh rumah tangga untuk membeli berbagai jenis kebutuhan dalam periode satu tahun tertentu. Pendapatan yang diterima oleh rumah tangga akan digunakan untuk membeli makanan, pakaian, layanan transportasi, membayar pendidikan anak-anak, membayar sewa rumah dan membeli kendaraan. Barang-barang dibeli oleh rumah tangga untuk memenuhi kebutuhan mereka (Sukirno, 1994). Menurut teori Schumpter, menekankan teorinya bahwa kemajuan ekonomi sangat ditentukan oleh peran wirausahawan. Pengusaha superior yang memiliki inisiatif tinggi, kemampuan, dan keberanian untuk menerapkan penemuan baru dalam kegiatan produksi mereka. Para pengusaha akan menciptakan hal-hal baru seperti membuat item baru menggunakan cara-cara baru dalam memproduksi pasar yang berkembang ke daerah-daerah baru yang mengembangkan sumber reorganisasi mentah baru dan restrukturisasi di perusahaan atau industri untuk kemajuan yang lebih baik.

\section{Pengaruh Investasi (X2) terhadap Pertumbuhan Ekonomi (Y)}

Hasil analisis regresi linier berganda menunjukkan bahwa Investasi (X2) berpengaruh positif dan signifikan terhadap Pertumbuhan Ekonomi (Y). Hal ini berarti, jika Investasi (X2) mengalami peningkatan, maka Pertumbuhan Ekonomi (Y) juga akan mengalami peningkatan yang signifikan. Hasil penelitian ini sesuai dengan hasil penelitian (Rafiq, 2016) yang menyatakan investasi berpengaruh positif atau signifikan terhadap pertumbuhan ekonomi. Menurut teori Harrod dan Domar, berpendapat bahwa suatu perekonomian akan tumbuh melesat dalam jangka panjang apabila adanya investasi. Upaya untuk mewujudkan investasi perlu meningkatkan tabungan, maka dari itu, pelaku ekonomi selalu menyisihkan sebagian pendapatan untuk meningkatkan tabungan. Tetapi dalam konsepnya, Harrod-Domar tetap memerlukan adanya peranan pemerintah untuk menghimpun dana investasi agar pertumbuhan ekonomi semakin meningkat dalam jangka panjang. Investasi merupakan suatu pembelian barang-barang modal dan peralatan produksi untuk meningkatkan suatu perekonomian di masa depan (Rusdiansyah, 2014). Investasi juga merupakan salah satu indikator pertumbuhan ekonomi suatu wilayah. Dengan adanya investasi yang bertujuan untuk pembelian barang-barang dan jasa akan dapat meningkatkan PDRB riil dan akan berpengaruh positif terhadap pertumbuhan ekonomi. Dari seluruh sektor penanaman modal yang dilakukan investor di Surabaya, yang paling besar adalah dari sektor non fasilitas. Dari data DPM-PTSP Surabaya, penerimaan dari penanaman modal asing terbilang kecil dibandingkan dengan penanaman modal non fasilitas. Hal ini berarti Kota Surabaya tidak bergantung pada investasi dari asing melainkan di Surabaya sendiri sudah cukup banyak yang berinvestasi. Dari sektor non fasilitas tersebut, investasi yang terbesar adalah bidang perdagangan sebesar 29 Miliar. Selain konsumsi rumah tangga dan investasi yang dapat mempengaruhi pertumbuhan 
PDRB, jumlah unit usaha juga termasuk salah satu indikator penting pada pertumbuhan ekonomi.

\section{Pengaruh Jumlah Usaha (X3) terhadap Pertumbuhan Ekonomi (Y)}

Hasil analisis regresi linier berganda menunjukkan bahwa Jumlah Usaha (X3) berpengaruh positif, tetapi tidak signifikan terhadap Pertumbuhan Ekonomi (Y). Hal ini berarti, jika Jumlah Usaha (X3) mengalami peningkatan, maka Pertumbuhan Ekonomi (Y) juga akan mengalami peningkatan yang tidak signifikan. Hasil penelitian ini sesuai dengan hasil penelitian (Julianto, 2016) yang menyatakan jumlah usaha berpengaruh positif atau signifikan terhadap pertumbuhan ekonomi. (Robiani, 2005) juga menyatakan bahwa penambahan nilai tambah sektor industri memberikan pengaruh yang signifikan terhadap pertumbuhan ekonomi di Sumatera Selatan. Hal tersebut berarti nilai tambah sektor industri adalah adanya peningkatan unit produksi, sehingga dengan bertambahnya unit produksi maka ada serapan tenaga kerja dan modal sehingga produksi pada sektor ini dapat meningkat dan akan mempengaruhi pertumbuhan ekonomi. Kota Surabaya sebagai pusat perekonomian di Jawa Timur, dimana banyak perusahaan baik skala global maupun nasional yang beroperasi di Surabaya. Maka dari itu dengan banyaknya sejumlah unit usaha yang berkembang dari tahun ke tahun di Surabaya juga dapat mempengaruhi pertumbuhan PDRB. Menurut teori Schumpeter, kemajuan perekonomian sangat ditentukan oleh adanya pengusaha. pengusaha yang unggul akan menciptakan suatu produksi yang unggul juga. Semakin bertambahnya jumlah produksi akan mempengaruhi pertumbuhan perekonomian di suatu wilayah.

\section{Kesimpulan}

Hasil analisis menunjukkan bahwa konsumsi rumah tangga berpengaruh positif dan signifikan terhadap pertumbuhan ekonomi Kota Surabaya. Hal ini berarti, jika konsumsi rumah tangga mengalami peningkatan, maka dapat berpengaruh terhadap perrtumbuhan ekonomi di Kota Surabaya. Hasil analisis regresi linier berganda menunjukkan bahwa investasi berpengaruh positif dan signifikan terhadap pertumbuhan ekonomi Kota Surabaya. Hal ini berarti, Investasi di Kota Surabaya berpengaruh terhadap pertumbuhan ekonomi. Hasil analisis menunjukkan bahwa jumlah usaha berpengaruh positif, tetapi tidak signifikan terhadap pertumbuhan ekonomi Kota Surabaya. Hal ini berarti, Jumlah Usaha tidak berpengaruh terhadap pertumbuhan ekonomi di Kota Surabaya. 
Ayu Putri Islamiah, Wiwin Priana, Muhammad Wahed

\section{BIBLIOGRAFI}

Anggoro, M. H. (2015). Pengaruh Pertumbuhan Ekonomi Dan Pertumbuhan Angkatan Kerja Terhadap Tingkat Pengangguran Di Kota Surabaya. Jurnal Pendidikan Ekonomi (Jupe), 3(3). Google Scholar

Azwar, S. (2000). Asumsi-Asumsi Dalam Inferensi Statistika. Buletin Psikologi, 9(1). Google Scholar

Basri, G., Walkowicz, L. M., Batalha, N., Gilliland, R. L., Jenkins, J., Borucki, W. J., Koch, D., Caldwell, D., Dupree, A. K., \& Latham, D. W. (2010). Photometric Variability In Kepler Target Stars. Ii. An Overview Of Amplitude, Periodicity, And Rotation In First Quarter Data. The Astronomical Journal, 141(1), 20. Google Scholar

Fau, J. F. (2018). Analisis Potensi Sektoral Ekonomi Kabupaten Nias Selatan Metode Analisis Shift-Share Dan Location Quotient. Jurnal Education And Development, 5(1), 26. Google Scholar

Gadeng, T. (2011). Analisis Faktor-Faktor Yang Mempengaruhi Konsumsi Masyarakat Di Provinsi Aceh. Jurnal Ilmiah Manajemen Muhammadiyah Aceh, 1(2).Google Scholar

Ghozali, M., Fauzi, L. R., \& Triwulandari, E. (2016). Sintesis Dan Uji Mekanik Epoksi Termodifikasi Poliuretan Berbasis Ester Gliserol Monooleat. Jurnal Kimia Terapan Indonesia (Indonesian Journal Of Applied Chemistry), 18(01), 45-54. Google Scholar

Gwijangge, L., Kawung, G. M. V, \& Siwu, H. (2018). Pengaruh Investasi Dan Tenaga Kerja Terhadap Pertumbuhan Ekonomi Provinsi Papua. Jurnal Berkala Ilmiah Efisiensi, 18(6). Google Scholar

Julianto, F. T. (2016). Analisis Pengaruh Jumlah Industri Besar Dan Upah Minimum Terhadap Pertumbuhan Ekonomi Di Kota Surabaya. Jeb17: Jurnal Ekonomi Dan Bisnis, 1(02).Google Scholar

Kuncoro, A. (2003). Microeconomic Determinants Of Economic Growth In East Asia. Economics And Finance In Indonesia, 51, 1-52. Google Scholar

Lumintang, F. M. (2013). Analisis Pendapatan Petani Padi Di Desa Teep Kecamatan Langowan Timur. Jurnal Emba: Jurnal Riset Ekonomi, Manajemen, Bisnis Dan Akuntansi, 1(3). Google Scholar

Mankiw, N. G. (2006). The Macroeconomist As Scientist And Engineer. Journal Of Economic Perspectives, 20(4), 29-46.Google Scholar

Rafiq, M. (2016). Pengaruh Pengeluaran Konsumsi Rumah Tangga, Investasi Dan Pengeluaran Pemerintah Terhadap Pertumbuhan Ekonomi Di Indonesia Tahun 
Analisis Pengaruh Konsumsi Rumah Tangga, Investasi, dan Jumlah Usaha terhadap Pertumbuhan Ekonomi di Kota Surabaya

2001: T1-2010: T4. Google Scholar

Robiani, B. (2005). Analisis Pengaruh Industrialisasi Terhadap Pertumbuhan Ekonomi Di Sumatera Selatan. Jurnal Ekonomi Dan Pembangunan Indonesia, 6(1), 93-103. Google Scholar.

Rusdiansyah, M. (2014). Pengaruh Konsumsi Rumah Tangga Dan Pengeluaran Pemerintah Terhadap Pertumbuhan Ekonomi Sulawesi Selatan Periode 20002012. Universitas Islam Negeri Alauddin Makassar.Google Scholar

Sukirno, S. (1994). Pengantar Teori Ekonomi Makro. Penerbit Raja Grafindo, Jakarta.Google Scholar

Tapparan, S. R. (2020). Analisis Korelasi Infrastruktur Jalan Terhadap Pertumbuhan Ekonomi Kabupaten Tana Toraja. Jurnal Ekonomika, 4(1), 68-72.Google Scholar

Utama, P. (2013). Ahmadi, A. 2009. Psikologi Umum Edisi Revisi. Jakarta: Rineka Cipta. Arikunto, S. 2006. Prosedur Penelitian Suatu Pendekatan Praktek. Jakarta: Pt. Rineka Cipta. Aunurrahman. 2009. Belajar Dan Pembelajaran. Bandung: Alfabeta. Azwar, S. 2006. Reliabilitas Dan Validitas. Yogyakarta: Pustaka Pelajar. International Journal, 1(1), 49-57.Google Scholar

Yuniandra, F., Kusmana, C., \& Nurrochmat, D. R. (2007). Formulasi Kebijakan Pengelolaan Hutan Bersama Masyarakat Di Taman Nasional Gunung Ciremai. Jurnal Manajemen Hutan Tropika, 13(3), 146-154.Google Scholar

Ginting, A. M. (2009). Prosespek Pertumbuhan Ekonomi Indonesia 2013: Suatu Analisis Pengaruh Pengeluaran Pemerintah, Konsumsi, Dan Ekspor Indonesia Terhadap Pertumbuhan Ekonomi Indonesia.Google Scholar

Sangaji, M. (2009). Fungsi Konsumsi Rumah Tangga di Indonesia (Pendekatan Model Koreksi Kesalahan). Journal of Indonesian Applied Economics, 3(2).Google Scholar

\section{Copyright holder :}

Ayu Putri Islamiah, Wiwin Priana, Muhammad Wahed (2021)

First publication right:

Jurnal Syntax Admiration

This article is licensed under:

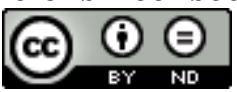

